\title{
96. On the Occurrence of the Tetraploid Plant of Rice, Oryza sativa $L$.
}

\author{
By Eiiti NAKAMORI. \\ Agricultural Experiment Station, Gihu. \\ (Comm. by S. IKENo, M.I.A., July 12, 1933.)
}

In 1932 the author made a brief communication in respect to the occurrence of the triploid mutant in rice. ${ }^{1)}$ In the same year an individual appeared among the $F_{1}$ progenies resulting from another varietal cross, ("Wase-Sinriki No. 23 " $\times$ "Kyô-Asahi") which was thought to be a new abnormal type. Cytological investigation of its root tip cells revealed that each metaphase plate contained uniformly 48 chromosomes. Its morphology exhibits no remarkable abnormalities, except in the ears. Like the triploid previously reported, its ears bear greatly enlarged spikelets with strongly developed awns, and in this case much more considerably than in the triploids. The number of spikelets per ear is reduced noticeably, being approximately $60 \%$ of that of the parental varieties.

Contrary to the author's expectation it is very poorly fertile and only $27 \%$ of the total spikelets borne on it are secured as well-formed grains.

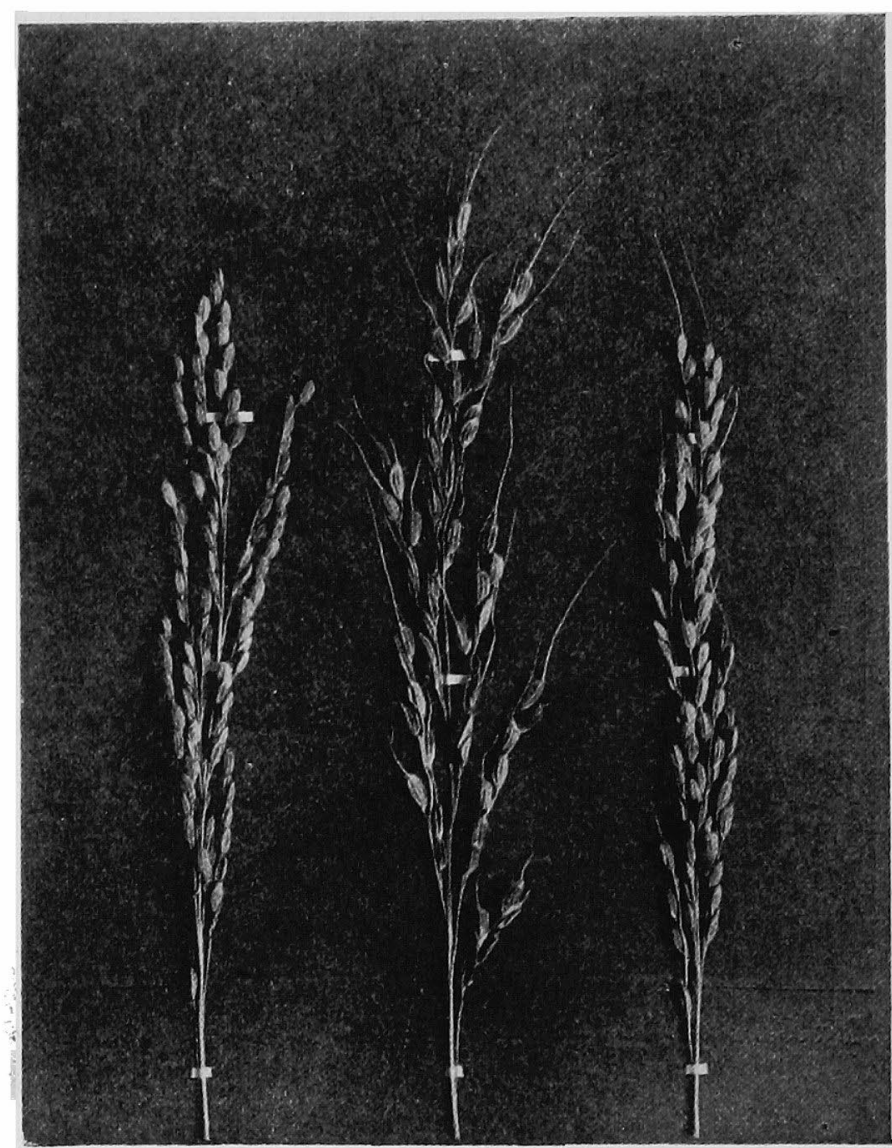

Fig. 1. Ears of the parental varieties and the tetraploid :
“Wase-Sinriki No. 23" (left), tetraploid (middle),
"Kyô-Asahi " (right).

1) Nakamori, E.: On the appearance of the triploid plant of rice, Oryza sativa $L$. Proc. 8 (1932), 10. 
No. 7.] On the Occurrence of the Tetraploid Plant of Rice, Oryza sativa $L . \quad 341$

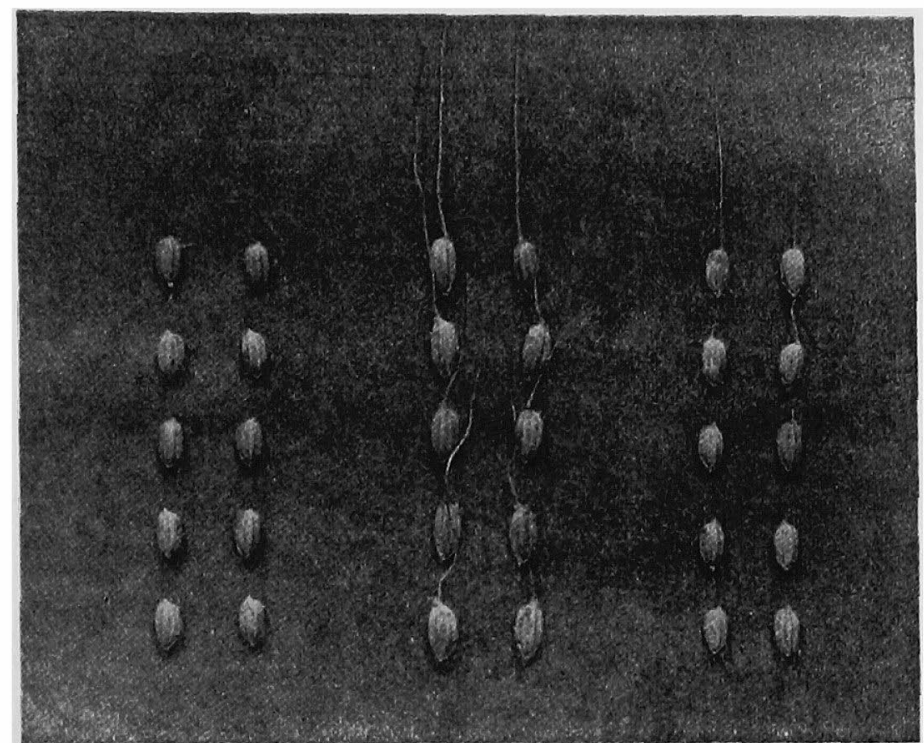

Fig. 2. Spikelets of "Wase-Sinriki No. 23" (left), tetraploid (middle), and "Kyô-Asahi" (right).

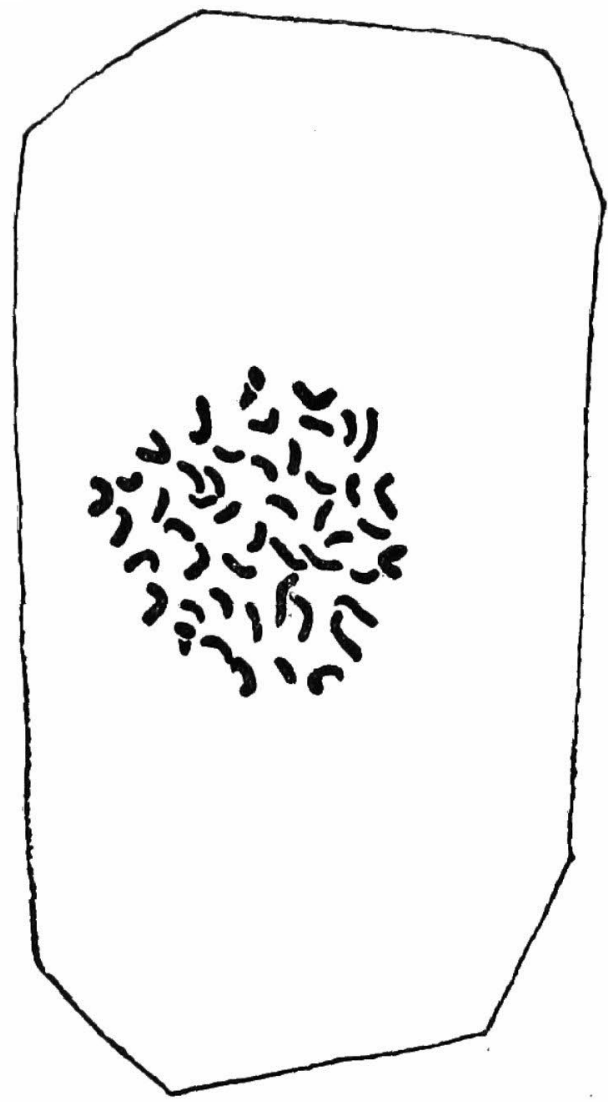

Fig. 3. Metaphase of the somatic mitosis in a root-tip cell of the tetraploid plant. 